\title{
A machiavellizmus kapcsolata viselkedéses és pszichés problémákkal serdülőkorban
}

\author{
Láng András dr. \\ Pécsi Tudományegyetem, Bölcsészettudományi Kar, Pszichológia Intézet, Pécs
}

\begin{abstract}
Bevezetés: A machiavellista személyiségvonással kifejezett formában rendelkező személyek egyik kiemelkedő jellemzője, hogy önös érdekeik elérésére manipulatív személyközi taktikákat alkalmaznak. Számos nemzetközi és hazai vizsgálat mutatott ki már összefüggést felnőttmintán machiavellizmus és pszichológiai nehézségek között. Célkitüzés: A nemzetközi szakirodalomban serdülők esetében is kimutattak már ilyen összefüggéseket, de hazai vizsgálat még nem született a témában. Módszer: Vizsgálatunkban 502 középiskolás (356 lány) töltötte ki a machiavellizmust és pszichológiai, illetve viselkedéses problémákat mérő kérdốveket. Eredmények: A machiavellista serdülőket magasabb összesített problémapontszám jellemezte. Ez a viselkedéses és érzelmi problémák jelenlétéből adódott, de ezenkívül a túlmozgásosság is megjelent a machiavellistákra jellemző problémák között. A proszociális viselkedés kevésbé jellemezte őket, ugyanakkor nem számoltak be nagyobb fokú magányosságról, mint kortársaik. Köpetkeztetések: Az eredményeket a korábbi kutatási eredmények, az érzelem- és viselkedésszabályozás tükrében vitatjuk meg. A gyakorlati alkalmazhatóság szempontjából kiemeljük a prevenció lehetőségeit. Orv. Hetil., 2015, 156(26), 1054-1058.
\end{abstract}

Kulcsszavak: machiavellizmus, érzelmi problémák, viselkedési problémák, kortárskapcsolatok, serdülőkor

\section{Relationship between Machiavellianism and emotional and behavioral difficulties in adolescence}

Introduction: Machiavellianism is a personality trait that is characterized by intense interpersonal manipulation in order to achieve personal material goals. Previous studies revealed a relationship between Machiavellianism and diverse forms of psychological difficulties in adults. Aim: Studies also revealed such relationships in adolescents as well, but studies investigating the relationship between Machiavellianism and psychological difficulties in adolescents are still absent in Hungary. Method: In this study 502 secondary school students ( 356 girls) filled out questionnaires that measured Machiavellianism and psychological and behavioral difficulties. Results: Machiavellianism was associated with higher total problem score. This resulted mainly from higher scores on scales measuring emotional and behavioral problems. Moreover, hyperactivity and lack of prosocial behavior were also associated with Machiavellianism. At the same time, Machiavellian adolescents did not differ in self-reported loneliness from their peers. Conclusions: The author discusses the results in the light of previous research and from the perspective of emotion and behavior regulation. Practical aspects of the results are also discussed in the context of prevention.

Keywords: Machiavellianism, emotional difficulties, behavioral difficulties, peer relationships, adolescence

Láng, A. [Relationship between Machiavellianism and emotional and behavioral difficulties in adolescence]. Orv. Hetil., 2015, 156(26), 1054-1058.

(Beérkezett: 2015. március 23.; elfogadva: 2015. április 30.)

A machiavellizmus Christie és Geis [1] munkája nyomán az 1970-es évektől kezdődően nagy figyelemmel kísért jelenséggé vált a pszichológia számos ágán belül. A machiavellizmust egy társas szempontból nemkívánatos, az átlagember számára visszatetszést keltő [2], sötét [3] személyiségvonásnak vagy attitüdnek tekintjük. Azok a személyek, akik kifejezett mértékben rendelkeznek ezzel az attitúddel, viselkedésüket morális értékek és etikai el- 
vek helyett saját érdekeikhez igazítják. Jelmondatuk: a cél szentesíti az eszközt. A machiavellista attitűd három összetevőből épül fel [1]. Személyközi kapcsolataikat manipulatív taktikákkal alakítják - hazudnak, hízelegnek, megtévesztenek. A világot és embertársaikat cinikus módon szemlélik, a környezetükben élőket olyan balekoknak tekintik, akik naivitásukkal, élhetetlenségükkel rászolgáltak arra, hogy kihasználják őket. Morális szempontból érzéketlenek; ha a szükség úgy diktálja, konform módon viselkednek, ha az áll érdekükben, figyelmen kívül hagyják a társadalmi szabályokat. A machiavellista személyek érzelmileg távolságtartók [4], mások közelségét csak addig igénylik, ameddig kihasználják áldozataikat. Fontos számukra ugyanakkor, hogy kapcsolataikat és az őket körülvevő helyzeteket ők irányítsák [5].

A serdülőkori machiavellizmus lényegében a felnőttkori megnyilvánulásához nagyon hasonló elemekből épül fel $[6,7]$. Ám míg a felnőtt machiavellisták egyértelmüen kevésbé kedvelt, negatívan megítélt személyek [8], erôszakos és kortársaikat bántalmazó [9, 10] mivoltuk ellenére a serdülőkorú machiavellistákat sokszor elbưvölő, jó társas képességekkel rendelkező és társaik által kedvelt fiatalokként állítják elénk a kutatások [1, 12]. Ennek okát bizonyos szerzők abban látják, hogy míg a felnőtt machiavellistákra az érzelmi és viselkedéses szabályozás hiányosságai egyaránt jellemzőek [13, 14, 15], addig a serdülőkorú machiavellisták esetében a szabályozás zavara leginkább az érzelmi területekre terjed ki [9].

A machiavellizmus és pszichológiai problémák kapcsolatának kutatása számos korábbi tanulmány tárgyát képezte. Hazai és nemzetközi vizsgálatok felnőttmintán kimutatták, hogy a machiavellizmus kapcsolatban áll a depresszióval [16], a személyiségzavarokkal - azok közül is leginkább a borderline személyiségzavarral és személyiségszerveződéssel $[17,18,19,20]$-, illetve az élettel való elégedettség hiányával [21]. Gyermekek és serdülőkorúak körében végzett vizsgálatok is rámutatnak, hogy a deviáns pszichológiai múködés kapcsolata a machiavellizmussal már a fejlődés viszonylag korai időszakában megjelenik. A machiavellista gyerekek alacsonyabb érzelmi intelligenciával és kevésbé fejlett tudatelmélettel rendelkeznek kortársaikhoz képest [22], és a machiavellizmus olyan személyiségjegyekkel áll kapcsolatban [23], amelyek pszichológiai és viselkedéses zavarokhoz vezetnek [24].

A fentiek tükrében vizsgálatunk célkitűzése az volt, hogy magyar serdülők mintáján megvizsgáljuk a machiavellizmus és viselkedéses, illetve pszichés problémák kapcsolatát. Hipotézisünk az volt, hogy azokra a serdülőkre, akik kifejezettebb machiavellista attitüdről számolnak be, jellemzőbb lesz az érzelmi és viselkedéses problémák előfordulása, illetve kevésbé lesz rájuk jellemző a proszociális, segítő viselkedés.

\section{Módszer}

\section{Minta és eljárás}

Vizsgálatunkban - szüleik informált beleegyezését követően - 502 középiskolás (356 lány) vett részt. Életkoruk átlagosan 16,03 év volt (szórás: 0,93 év). A később ismertetendő mérőeszközökből álló kérdőívcsomagot iskolájukban, 25-35 fős osztályokban töltötték ki. A kitöltés vizsgálati asszisztens jelenlétében történt, önkéntes és anonim módon.

\section{Méröeszközök}

A machiavellista személyiségvonások mérésére a MachIV skálát [1] használtuk. A Mach-IV skála egy húsz állításból álló önkitöltős kérdőív, amely a fentiekben ismertetett önös, megtévesztő és másokat kihasználó beállítódást méri. A húsz állítás (például „Kerülő utak nélkül nehéz az életben előrejutni”) összesített pontszámát globális machiavellizmusmérő számként használtuk az elemzésekben. A skála belső megbízhatóságát az 1. táblázat tartalmazza.

A pszichés tünetek és viselkedéses problémák mérésére a Képességek és Nehézségek Kérdőív magyar változatát [25] használtuk. A 25 állításos, önkitöltős kérdőív négy problémaskálán keresztül méri a pszichés tünetek fő csoportjait. Az Érzelmi tünetek skála állításai (például „Sokat aggódom") a depresszív és szorongásos tünetekre kérdeznek rá; a Hiperaktivitás skála állításai (például „Könnyen elterelődik a figyelmem, nehezemre esik koncentrálni”) a túlmozgásosságra és figyelmetlenségre vonatkoznak. A Viselkedéses problémák skála állításai (például „Gyakran hazugsággal vagy csalással vádolnak”) a magatartásbeli problémákhoz kapcsolódó tünetekre és a társas normák megsértéseire, míg a Kortárskapcsolati problémák skála állításai (például „Többnyire egyedül vagyok; általában elvonulok, egyedül játszom”) a magányosságra, társas kirekesztettségre kérdeznek rá. A fenti négy skála összegzésével egy összesített problémapontszámhoz jutunk. Ezenkívül egy ötödik skála (Proszociális skála) állításai (például „Segítek, ha valakit bántottak, feldúlt vagy beteg”) a kortársak irányába megnyilvánuló empátiát, megosztásra való hajlandóságot mérik. A skálák belső megbízhatósági mutatói a korábbi magyar tanulmányokhoz [25, 26] hasonló értéket mutattak (1. táblázat).

\section{Statisztikai elemzés}

A statisztikai elemzéseket az IBM SPSS 19.0 for Windows programcsomaggal végeztük. A leíró statisztikák és a kérdőívskálák belső megbízhatóságának kiszámítása mellett a nemek közti különbségek vizsgálatára varianciaanalízist végeztünk. A machiavellizmus és a pszichés problémák kapcsolatának vizsgálatára Pearson-féle korrelációt, a machiavellizmus bejóslásában szerepet játszó 
pszichés zavarok feltárására hierarchikus többszörös lineáris regresszióelemzést végeztünk. Erre elsősorban a tünetek mögött meghúzódó közös, de nem mért jelenségek (például szorongásos zavarok) kiszűréséhez, illetve a nem hatásának kontrollálásához volt szükség.

\section{Eredmények}

Elsőként a mért változókon mutatkozó nemi különbségeket teszteltük. A varianciaanalízis eredményeit az 1. táblázat mutatja be. A fiúkra szignifikánsan jellemzőbb volt a machiavellista attitűd, mint a lányokra. A lányok ezzel szemben gyakoribb érzelmi tünetekről (depresszióról és szorongásról) és általánosságban is gyakoribb pszichés és viselkedéses problémákról számoltak be, mint a fiúk. Ezenkívül a lányokra jellemzóbb volt a proszociális viselkedés, mint a fiúkra.

A Pearson-féle korreláció eredményeként szignifikáns összefüggést kaptunk a serdülők machiavellista nézetei és viselkedéses problémái $(\mathrm{r}=0,25 ; \mathrm{p}<0,001)$, túlmozgásosságban és figyelmetlenségben megnyilvánuló tünetei $(\mathrm{r}=0,21 ; \mathrm{p}<0,001)$, proszociális viselkedésük hiánya $(\mathrm{r}=-0,32 ; \mathrm{p}<0,001)$ és a pszichés problémák összesített gyakorisága $(\mathrm{r}=0,21 ; \mathrm{p}<0,001)$ között. A machiavellizmus és a kortárskapcsolati problémák között nem volt kimutatható összefüggés.
A hierarchikus többszörös lineáris regressziós elemzés eredményeit a 2. táblázat tartalmazza. Az elemzés megerősítette a varianciaanalízis által már feltárt összefüggést, miszerint a fiúkra jellemzőbb a machiavellizmus, mint a lányokra (első modell). A második modellből kiderült, hogy a nem kontrollálása mellett a viselkedéses problémák és a proszociális viselkedés hiánya szignifikánsan magasabb machiavellista attitúdöt jósolt be. Emellett tendenciaszerű erôsséggel az érzelmi tünetek és a hiperaktivitás is a machiavellizmust bejósló tényezőnek bizonyultak; mindkét esetben pozitív összefüggés mutatkozott. A korrelációs elemzésekhez hasonlóan a regressziós elemzés sem mutatott ki összefüggést a machiavellizmus és a kortárskapcsolati problémák között.

\section{Megbeszélés}

Eredményeink részben igazolták hipotéziseinket. A machiavellista attitüddel nagyobb mértékben azonosuló serdülők több érzelmi (tendenciaerôsségű kapcsolat) és elsődlegesen viselkedési problémáról számoltak be, mint kevésbé machiavellista kortársaik. Emellett a machiavellista személyiségjegyekkel inkább rendelkező fiatalok alacsonyabb proszociális attitűdről számoltak még be. Bár az összefüggésre hipotézist nem állítottunk fel, gyenge, de szignifikáns kapcsolat mutatkozott túlmozgásosság és

1. táblázat | Nemi különbségek a vizsgált változókon; a varianciaanalízisek eredményei és a kérdő́ivskálák belső megbízhatósága

\begin{tabular}{|c|c|c|c|c|c|c|c|}
\hline & \multicolumn{2}{|c|}{ Fiúk $(\mathrm{n}=146)$} & \multicolumn{2}{|c|}{ Lányok (n = 356) } & \multirow[t]{2}{*}{$\mathrm{F}$} & \multirow[t]{2}{*}{$\mathrm{p}$} & \multirow[t]{2}{*}{ Cronbach- $\alpha$} \\
\hline & Átlag & Szórás & Átlag & Szórás & & & \\
\hline Mach-IV & 98,88 & 12,28 & 94,22 & 10,76 & 17,889 & $<0,001$ & 0,56 \\
\hline SDQ - Érzelmi tünetek & 1,99 & 1,81 & 3,79 & 2,36 & 68,173 & $<0,001$ & 0,70 \\
\hline SDQ - Viselkedéses problémák & 2,08 & 1,39 & 2,21 & 1,17 & 1,019 & $=0,313$ & 0,29 \\
\hline SDQ - Hiperaktivitás & 3,80 & 1,97 & 3,96 & 2,09 & 0,600 & $=0,439$ & 0,61 \\
\hline SDQ - Kortárskapcsolati problémák & 1,58 & 1,42 & 1,80 & 1,46 & 2,554 & $=0,111$ & 0,45 \\
\hline SDQ - Proszociális skála & 7,02 & 1,66 & 7,45 & 1,73 & 6,536 & $<0,05$ & 0,57 \\
\hline SDQ - Összesített problémapontszám & 9,45 & 4,30 & 11,76 & 4,71 & 26,074 & $<0,001$ & 0,71 \\
\hline
\end{tabular}

2. táblázat |A machiavellizmust bejósló változók; a hierarchikus többszörös lineáris regresszió eredményei

\begin{tabular}{|c|c|c|c|c|c|}
\hline Modell & Prediktor változók & $\Delta \mathrm{R}^{2}$ & $\beta$ & $\mathrm{t}$ & $\mathrm{p}$ \\
\hline 1. modell & Nem (lány) & 0,035 & $-0,186$ & $-4,230$ & $<0,001$ \\
\hline \multirow[t]{6}{*}{ 2. modell } & Nem (lány) & 0,142 & $-0,199$ & $-4,526$ & $<0,001$ \\
\hline & SDQ - Érzelmi tünetek & & 0,089 & 1,816 & $=0,070$ \\
\hline & SDQ - Viselkedéses problémák & & 0,144 & 3,151 & $<0,005$ \\
\hline & SDQ - Hiperaktivitás & & 0,089 & 1,909 & $=0,057$ \\
\hline & SDQ - Kortárskapcsolati problémák & & 0,008 & 0,184 & $=0,854$ \\
\hline & SDQ - Proszociális skála & & $-0,247$ & $-5,778$ & $<0,001$ \\
\hline
\end{tabular}

Függő változó: Mach-IV pontszám; $\Delta \mathrm{R}^{2}$ mindkét esetben szignifikáns $\mathrm{p}<0,05$ szinten. 
machiavellizmus között is. Eredményeink értelmezésekor fontos vizsgálatunk két módszertani korlátját is szem előtt tartanunk. Bár a Képességek és Nehézségek Kérdőív megbízhatósági mutatói megegyeztek a korábbi hazai alkalmazásakor nyertekkel [25, 26], az alacsonyabb értékek (Cronbach- $\alpha<0,50)$ bizonyos skálákkal nyert összefüggések esetén óvatosságra intenek. Vizsgálatunk másik módszertani korlátja, hogy adataink pusztán a serdülők önjellemzésére épülnek. A téma további kutatásában célszerü lenne szülőket vagy pedagógusokat is informátorként bevonni.

A fent ismertetett hiányosságok ellenére eredményeink jól értelmezhetőek és jól illeszkednek az elméleti bevezetőben bemutatott korábbi eredményekhez. Vizsgálatunk megerősítette azokat az elsősorban felnőttekkel végzett kutatásokból származó eredményeket, miszerint a kifejezettebb machiavellizmus magasabb szintü depresszióval [16] és gyakoribb agresszióval [19] áll kapcsolatban. A machiavellizmus túlmozgásossággal való kapcsolata váratlan eredménynek tünik, különösen azon megállapítás fényében, amely a serdülőkorú machiavellistáknál az érzelmi szabályozás zavarait kifejezettebbnek tartja a viselkedéses szinten megjelenóknél [9]. Ugyanakkor arról sem szabad megfeledkeznünk, hogy a hiperaktivitás és a figyelmetlenség a depresszió és szorongás tünete is lehet. A proszociális viselkedés hiánya a machiavellista serdülőknél nem meglepő: a machiavellisták kifejezetten önös beállítottságúak [1], a közösségi értékeket kevésbé tartják fontosnak [27], empátiájuk alacsony [22].

Bár a fenti eredmények ígéretesek, az oki összefüggést a pszichés, illetve viselkedéses problémák és a machiavellizmus között további kutatásoknak kell feltárniuk. Elméletben mindkét irányú okozást elképzelhetőnek tartjuk. A machiavellista személyiségvonások a társuló érzelemszabályozási nehézségek [9] miatt rizikófaktort jelenthetnek a később kialakuló pszichés rendellenességekre. Másrészt a machiavellizmustól eltérő okokból kialakuló érzelmi és viselkedéses problémák az általuk okozott szenvedés és életviteli nehézségek miatt egy megkeseredett és cinikus világlátáshoz vezethetnek. Az ilyen módon érzékelt világban boldogulást csupán mások manipulálása jelenthet.

További eredményként adódott, hogy nem találtunk összefüggést machiavellizmus és kortárskapcsolati problémák között. Kézenfekvő magyarázatnak tưnhet a fent már említett módszertani korlátra hivatkoznunk, miszerint a vizsgálatban részt vevő serdülők önmagukat jellemezték. Az eredmények ilyen módon történő értelmezése szerint azok pusztán az önészlelésre vonatkoznak; a machiavellista serdülők nem látják magukat társaiktól különbözőnek társas helyzetük, közösségi pozíciójuk tekintetében. Ezt a fajta önészlelést jól magyarázhatja a machiavellisták elkerülő kötődése [4]. Az elkerülő kötődésű személyek kapcsolati szükséglete jellegzetesen alacsony, kerülik mások pszichológiai közelségét, így esetleges elszigeteltségüknek sem tulajdonítanak nagy jelentőséget, nem élik meg magányosságukat negatívként. Másrészt az önjellemzés ellenére hiteles eredménynek is tarthatjuk, hogy a machiavellista serdülök nem rendelkeznek rosszabb társas pozícióval. Korábbi vizsgálatokban $[11,12]$ számos negatívan értékelt tulajdonságuk - például a jelen vizsgálatban is megmutatkozó agresszió és aszociális attitüd - ellenére jó társas képességekkel rendelkező és társaik körében kedvelt személyeknek találták őket. Az eredmény jól illeszkedik annak a vizsgálatnak az eredményeihez is, amelyben serdülők népszerü kortársaik két csoportját különböztették meg [28]. Az első csoport a közkedvelt népszerúek csoportja volt, amelybe a segítókész, barátságos és tanulmányaik iránt elkötelezett fiatalok tartoztak. A másik csoportot a szerzők által populistának nevezett fiatalok alkották. Ők arrogánsak és kapcsolataikban gyakran agresszívek voltak, tanulmányaik iránt alacsony elkötelezettséget mutattak, de vezetésre, befolyásolásra való képességeik mégis népszerúvé tették őket kortársaik körében. Ez a leírás vizsgálatunk eredményei alapján is - kiválóan ráillik a machiavellista serdülőkre.

Vizsgálatunk gyakorlati értékét az adhatja, hogy a pszichológiai problémák mellett nem sikerült kortárskapcsolati problémákat kimutatni a machiavellista serdülők körében. A kortárskapcsolatok zavara érzékeny mutatója a serdülőkori fejlődés kisiklásának [29]. Mivel a machiavellista serdülők viselkedési és érzelmi problémáik mellett nem mutatnak kortárskapcsolati problémákat, ez fokozott veszélyeztetettséget jelenthet számukra a későbbi pszichés problémák szempontjából. Ilyen érzékeny mutató híján ugyanis láthatatlanok maradhatnak a lelki egészség kapuőrei (például pedagógusok, ifjúságsegítők) és az esetleges prevenciós programok számára.

Anyagi támogatás: A kutatás a TÁMOP 4.2.4.A/2-11-1-2012-0001 azonosítószámú Nemzeti Kiválóság Program - Hazai hallgatói, illetve kutatói személyi támogatást biztosító rendszer kidolgozása és múködtetése konvergenciaprogram című kiemelt projekt keretében zajlott. A projekt az Európai Unió támogatásával, az Európai Szociális Alap társfinanszírozásával valósul meg.

A szerző a kézirat végleges változatát elolvasta és jóváhagyta.

Érdekeltségek: A szerzőnek nincsenek érdekeltségei.

\section{Irodalom}

[1] Christie, R., Geis, F. L.: Studies in Machiavellianism. Academic Press, New York, 1970.

[2] Lee, K., Ashton, M. C.: Psychopathy, Machiavellianism, and narcissism in the five-factor model and the HEXACO model of personality structure. Pers. Individ. Differ., 2005, 38, 1571-1582.

[3] Paulhus, D. L., Williams, K. M.: The dark triad of personality: Narcissism, Machiavellianism, and psychopathy. J. Res. Pers., 2002, 36, 556-563. 
[4] Wilson, D. S., Near, D., Miller, R. R.: Machiavellianism: a synthesis of the evolutionary and psychological literatures. Psychol. Bull., 1996, 119(2), 285-299.

[5] Ináncsi, T., Láng, A., Bereczkei, T.: Machiavellianism and adult attachment in general interpersonal relationships and close relationships. Eur. J. Psychol., 2015, 11(1), 139-154.

[6] Chabrol, H., Van Leeuwen, N., Rodgers, R. et al.: Contributions of psychopathic, narcissistic, Machiavellian, and sadistic personality traits to juvenile delinquency. Pers. Individ. Differ., 2009, 47, 734-739.

[7] Sutton, J., Keogh, E.: Components of Machiavellian beliefs in children: Relationships with personality. Pers. Individ. Differ., 2001, 30, 137-148.

[8] Rauthmann, J. F.: The dark triad and interpersonal perception: Similarities and differences in the social consequences of narcissism, Machiavellianism, and psychopathy. Soc. Psychol. Person. Sci., 2012, 3(4), 487-496.

[9] Lau, K. S., Marsee, M. A.: Exploring narcissism, psychopathy, and Machiavellianism in youth: Examination of associations with antisocial behavior and aggression. J. Child Fam. Stud., 2013, 22(3), 355-367.

[10] Andreou, E.: Bully/victim problems and their association with Machiavellianism and self-efficacy in Greek primary school children. Br. J. Educ. Psychol., 2004, 74(2), 297-309.

[11] McIlwain, D.: Bypassing empathy: A Machiavellian theory of mind and sneaky power. In: Repacholi, B., Slaughter, V. (eds.): Individual differences in theory of mind. Psychology Press, New York, 2003, 39-66.

[12] Repacholi, B., Slaughter, V., Pritchard, M., et al.: Theory of mind, Machiavellianism, and social functioning in childhood. In: Repacholi, B., Slaughter, V. (eds.): Individual differences in theory of mind. Psychology Press, New York, 2003, 67-98.

[13] Wastell, C., Booth, A.: Machiavellianism: An alexithymic perspective. J. Soc. Clin. Psychol., 2003, 22(6), 730-744.

[14] Birkás, B., Csathó, Á., Gács, B., et al.: Nothing ventured nothing gained: Strong associations between reward sensitivity and two measures of Machiavellianism. Pers. Individ. Differ., 2014, 74, $112-115$.

[15] Jonason, P. K., Tost, J.: I just cannot control myself: The dark triad and self-control. Pers. Individ. Differ., 2010, 49, 611-615.

[16] Bakir, B., Yilmaz, U. R., Yavas, I.: Relating depressive symptoms to Machiavellianism in a Turkish sample. Psychol. Rep., 1996, 78(3 Pt 1), 1011-1014.

[17] Douglas, H., Bore, M., Munro, D.: Distinguishing the dark triad: Evidence from the five-factor model and the Hogan development survey. Psychology, 2012, 3, 237-242.

[18] McHoskey, J. W.: Machiavellianism and personality dysfunction. Pers. Individ. Differ., 2001, 31, 791-798.
[19] Láng, A.: Machiavellianism and personality disorder: their relationship in the mirror of interpersonal attitudes. [Machiavellizmus és személyiségzavar összefüggései az interperszonális kapcsolatok tükrében.] Orv. Hetil., 2014, 155(40), 1584-1588. [Hungarian]

[20] Láng, A.: Borderline personality organization predicts Machiavellian interpersonal tactics. Pers. Individ. Differ., 2015, 80, 2831 .

[21] Ali, F., Chamorro-Premuzic, T.: The dark side of love and life satisfaction: Associations with intimate relationships, psychopathy and Machiavellianism. Pers. Individ. Differ., 2010, 48, 228233.

[22] Barlow, A., Qualter, P., Stylianou, M.: Relationships between Machiavellianism, emotional intelligence and theory of mind in children. Pers. Individ. Differ., 2010, 48, 78-82.

[23] Muris, P., Meesters, C., Timmermans, A.: Some youths have a gloomy side: Correlates of the dark triad personality traits in non-clinical adolescents. Child Psychiatry Hum. Dev., 2013, $44(5), 658-665$.

[24] Muris, P., Meesters, C., Diederen, R.: Psychometric properties of the Big Five Questionnaire for Children (BFQ-C) in a Dutch sample of young adolescents. Pers. Individ. Differ., 2005, 38(8), 1757-1769.

[25] Birkás, E., Lakatos, K., Tóth, I., et al.: Screening childhood behavior problems using short questionnaires I.: The Hungarian version of the Strengths and Difficulties Questionnaire. [Gyermekkori viselkedési problémák felismerésének lehetőségei rövid kérdőívekkel I.: A Strengths and Difficulties Questionnaire magyar változata.] Psychiatr. Hung., 2008, 23(5), 358-365. [Hungarian]

[26] Turi, E., Tóth, I., Gevai, J.: Further examination of the Strengths and Difficulties Questionnaire (SDQ-Magy) in a community sample of young adolescents. [A Képességek és Nehézségek Kérdőív (SDQ-Magy) további vizsgálata nem-klinikai mintán, fiatal serdülőkk körében.] Psychiatr. Hung., 2011, 26(6), 415426.

[27] Trapnell, P. D., Paulhus, D. L.: Agentic and communal values: Their scope and measurement. J. Pers. Assess., 2012, 94(1), 39-52.

[28] De Bruyn, E. H., Cillessen, A. H.: Popularity in early adolescence: Prosocial and antisocial subtypes. J. Adolescent. Res., 2006, 21(6), 607-627.

[29] Laufer, M., Laufer, M. E.: Adolescence and developmental breakdown. Yale University Press, London, 1984.

(Láng András dr., Pécs, Ifjúság útja 6., 7624 e-mail: andraslang@hotmail.com) 